Available Online at http://journal.unismuh.ac.id/index.php/otoritas

Otoritas : Jurnal Ilmu Pemerintahan, 8 (1), April 2018, 65-81

\title{
Disaster Management Concept of Muhammadiyah Disaster Management Centre in Ponorogo, Indonesia
}

\author{
Yusuf Adam Hilman*) \\ Department of Governmental Science, Faculty of Social and Political Sciences, \\ Universitas Muhammadiyah Ponorogo, Jl. Budi Utomo No.10, Ronowijayan, Siman, Kab. Ponorogo, \\ Jawa Timur 63471 Indonesia.
}

Received: 29 July 2017; Revised: 3 Desember 2017; Accepted: 4 Desember 2017

\begin{abstract}
Muhammadiyah Disaster Management Centre as an organization under Muhammadiyah Union, has a unique disaster management model, although it has not been established yet, MDMC has proven its existence. This progress is very interesting because it is very closely related to the Islamic concept which makes this organization different from other organizations. This background is very interesting to study. Besides, the concept and pattern of MDMC organization has not been popularly identified yet. This study aims to know and describe management disaster concept proposed by Muhammadiyah Disaster Management Centre (MDMC). It is to verify organizational pattern and Muhammadiyah Disaster Management Centre (MDMC) profile. This study utilizes interpretative paradigm with qualitative model. Based on the study conducted, it can be summarized that Al-Maun spirit has influenced and characterized MDMC organization on implementing disaster management activities. The spirit is reflected by how the management of mutually supportive organizations to achieve common goals. It is in order to help each other or mustadi'in. This is achieved by having partnership with Muhammadiyah autonomous institutions, as well as other parties such as government and private parties. There is a humanist concept beyond Al-Maun spirit. It is sharing and caring for people. It is implemented by MDMC through disaster management activities, from identifying, reconstructing, rehabilitating, to normalizing the victims. Seen from its existence, these activities lead MDMC to have a good vision in implementing disaster management.
\end{abstract}

Keywords: Al-Maun; disaster management; Muhammadiyah Disaster Management Centre

How to Cite: Hilman, Y. A. (2018). Disaster Management Concept of Muhammadiyah Disaster Management Centre in Ponorogo, Indonesia. Otoritas : Jurnal Ilmu Pemerintahan, 8 (1), 65-81.

Permalink/DOI: https://doi.org/10.26618/ojip.v8i1.807

${ }^{*}$ Corresponding Author.

E-Mail : adamhilman@umpo.ac.id

Copyright (C) 2018, Otoritas : Jurnal Ilmu Pemerintahan, ISSN: 2088-3706 (Print), ISSN: 2502-9320 (Online) 
Available Online at http://journal.unismuh.ac.id/index.php/otoritas

Otoritas : Jurnal Ilmu Pemerintahan, 8 (1), April, 2018, 66

\section{INTRODUCTION}

East Java Province is known as Majapahit kingdom civilization such as the arts of Reyog in Ponorogo, Bromo mountain tourism in Probolinggo, and agro-tourism area in Batu City. However, there is a potential disaster beyond this beautiful nature. Being located on the Pacific Ring of Fire (an area with a high degree of tectonic activity), Indonesia, particularly East Java has to cope with the constant risk of volcanic eruptions, earthquakes, and floods. East Java is generally divided into 2 geographical areas, mainland and coastal areas. Madura is one of biggest coastal area in East Java. Mainlad in East Java is $90 \%$ from total and it is $10 \%$ from total in Madura. East Java reaches 47,995 $\mathrm{sq} \mathrm{km}$ divided into approximately 38 districts / cities, with details of 39 districts and 9 cities.

Indonesian landscapes offer magical beauty. However, it has also cope with various constant risks. Particularly in East Java, there are risky disaster such as floods, landslides, fires, and etc. Natural resources overexploitation is suspected to be the major cause (BNPB, 2016).

According to BNPB, East Java has approximately 22 regencies and cities that have to cope with constant risk of floods and landslides. Those regencies and cities are Pacitan, Tulungagung, Trenggalek, Ponorogo, Blitar, Banyuwangi, South Malang, and Jember. Besides, there are also horseshoe areas such as Probolinggo and Situbondo. Transition period from dry to rainy season and the influence of La Nina storm affect constant risk of floods and landslides. Therefore, the viligance of the society is highly needed in this case (Media Indonesia, 2016).

All East Java's areas have to cope with potential natural disasters, such as floods, landslides, earthquakes, and volcanoes eruptions, so it can be ascertained when certain seasons, these areas are potentially affected by the disaster. Disaster is unpredictable, but it is clear that in order to minimize the losses incurred, it needs a good disaster management practices.Management Practice of disaster management has been done by government agency of BNPB (National Disaster Management Agency) along with BASARNAS, TNI and POLRI officers. These efforts include mapping of the region, evacuating, and post-disaster rehabilitating. If we look at the experiences of disaster management that have been done, there are several problems that arise.

Disasters can trigger other catastrophic risks. The condition causes every year people suffer from disasters. The government absolutely requires large amounts of funds to tackle disasters and restore post-disaster areas. The problem is that the number of events set as a disaster will have an impact on funding and the distribution of resources.In addition, the institutional problems of the Regional Disaster Management Agency (BPBD) and the management of unprofessional disaster relief can also affect the accountability and transparency of disaster management and disaster relief management. This study was conducted through a literature review of policies related to disaster management (Kurniawati, 2015).

In short, Sudibyakto concludes that the causes of poor disaster management planning are caused by several factors. Those factors are the understanding of local bureaucrats (PEMDA). They assume that disaster management institutions (in this case BPBD) only work when the disaster occurs so that pre-disaster PB planning which includes prevention, mitigation and preparedness is not a priority. Or in other words disaster management planning is reactive rather than proactive.In line with Sudibyakto, Kartasasmita claims that planning failure may be caused by inappropriate planning. this may happen because the information and planning follow a paradigm that turns out to be incompatible with conditions 
and developments where this refers to the understanding of disaster management paradigm that is more reactive rather than pro-active. Therefore, it cannot solve the basic problem of disaster management. In addition, the planning does not provide an opportunity for the development of individual initiatives and capacity building and the full potential of the community, where community participation and involvement in this case need to be continually facilitated and empowered. It is expected that they have have awareness and feel the need for the importance of disaster management (Ahdi, 2015).

Several regulations to anticipate disasters have been administered. However, in fact, there are still many shortcomings in disaster management practices. One example of disaster management communication practices that have not been maximized can be seen in earthquake disaster in Special Region of Yogyakarta and Central Java.Based on studies conducted by Lestari, Sembiring, Prabowo Wibawa, \& Hendariningrum (2013), it is found that there is a conflict in lower level society (the victims) to the central government level. The causes of conflicts are varied, from the distribution of aid during emergency response to reconstruction and rehabilitation. The types of conflicts are varied, such as intrapersonal (stress) conflicts, between groups (among volunteers, inter-donors, governments versus NGOs, government versus government), policy issues, and earthquake relief corruption cases.

In addition to technical matters, there is a complexity in disaster management that often becomes a problem. It is non-government institutions that less focus and concentrate on disaster management, so that when disaster occurs, government agencies are unable or overwhelmed in solving the problem.The complexity of disasters in Indonesia, should be addressed by all parties who are for- mally responsible for the natural disasters and other social disasters. The number of natural disasters that increase need to be tackled by both the government and society. The social and economic impact are not easy to be addressed quickly by the government itself, as the party that is responsible to ensure public safety. (Syarif \& Unde, 2014).

Muhammadiyah organization as one of the social organizations, also has disaster management institution, namely: Muhammadiyah Disaster Management Center (MDMC). Although it has not been established, since 2009, it has also been instrumental in the process of disaster management. Its existence is also important; preparing the disaster management process, caring for each other, as God's creatures.The existence of MDMC is interesting, because this institution has an organizational structure from central to regional. Therefore, it is possible for MDMC to directly tackle problems from disaster in their regions.

MDMC conducted basic training II of Disaster Relief Volunteers in Coban Rondo Malang. This activity was followed by 34 participants from high school students, university students and public society. This training aims to strengthen community competence in implementing disaster management practices so there will be trained and professional personnels in MDMC.

The result of the study related to MDMC Malang Regency Role in the management disaster process has discussed some points. Those points are a). Mitigation Stage, b). Preparedness Stage, c). Emergency Response Stage, d). Rehabilitation Stage (Agustina, 2016).

Muhammadiyah and its units conducted free medical treatment programs in Ponorogo area. The activity is named as Volunteer Muhammadiyah Ponorogo. They also conducted various social activities in the Talun area of Ngebel Ponorogo subdistrict, by cleaning up the former 
landslide disaster and providing assistance (PDM Ponorogo, 2016).

MDMC is very interesting, because it is formed from Muhammadiyah organization based on Islamic law. Therefore, in organizing and controlling disaster management, there are different and unique models with government institutions such as BNPB, BASARNAS. Based on this reason, the researcher is interested to see how far the concept of disaster management offered by MDMC. Organizational patterns and management practices of disaster management initiated by MDMC need to be known and understood, so that efforts to solve disaster problems can be optimal, without depending on the government. It is to consider that the government also has limitations in the implementation of disaster management, so that other alternatives can be used as a solution.

Background of the study above gives us a description of alternative solution of disaster management implemented by MDMC. It is as an effort of nongovernmental organizations' participation in disaster management efforts, so that the concepts initiated by MDMC can be peeled and also revealed, whether or not it is really effective; related to disaster management concept with MDMC Islamic organization model.This study focuses on the concept of disaster management proposed by Muhammadiyah Disaster Management Centre (MDMC). This study aims to: 1) know and describe disaster management concept proposed by Muhammadiyah Disaster Management Centre (MDMC); 2) verify organizational patterns and profile of Muhammadiyah Disaster Management Center (MDMC, 2012).

caused by the following factors: bad execution (bad implementation), bad policy or bad luck (policy which is a bad luck). Therefore, the study purpose for describing the implementation of policy Minimum Service Standards in dr. H. Koesnadi Bondowoso general hospital, and analyz- ing the inhibiting factors of it that caused the low quality of health service in dr. $\mathrm{H}$. Koesnadi Bondowoso general hospital.

This research would discuss the policy implementation of minimum service standards by using Edward III concept as a tool to analyze it. As previous studies on policy implementation using Edward III theory such as those have been done by Nurani (2009), Sukowati (2013), Saputra \& Suranto (2016), Kusnadi (2015), and Matto (2016). However, no one gone further with the factors affecting the policy implementation of the minimum service standards and largely explains only the variables of Edward III theory which include communication, sources, disposition and bureaucratic structure. In addition, although previous research has investigated more closely the factors affecting policy implementation such as that of Aneta (2010), but the focus of the study was different from this research. Beside factors based on Edward III theory, this study will also explore about leadership factors in controlling aspects of sectoral ego in the policy implementation of minimum service standards at the hospital. The existence of leadership factors that will be studied, will be a distinguishing factor with previous research that is expected to contribute for the successful implementation of public policy in the future.

\section{RESEARCH METHODS}

The paradigm of a study is the research perspective that the researcher uses. It contains how the researcher sees reality, how to study phenomena, the methods used in the research and the ways used in interpreting the findings. In the context of the research design, the selection of the research paradigm illustrates the choice of a trust that will underlie and guide the entire research process. The research paradigm determines what the problem is and what type of explanation it can receive (Chariri, 2009.) 
This study employes interpretative paradigm to analyze the concept implemented by MDMC (Muhammadyah Disaster Management Centre), an institution that has management disaster concept. Its concept is based on Islamic Law since MDMC is under the umbrella of Muhammadiyah organization.

Interpretative paradigm comes from Germany philosophy that focuses on the role of language, interpretation, and understanding in social sciences. This approach focuses on subjective from social world and it tries to understand from its studied objective framework. Therefore, the focus is on individual meaning and human perception on reality rather than on the independent reality that lies beyond them.

Humans continually create their social reality in order to interact with others. The purpose of the interpretive approach is to analyze such social reality and how social reality is formed (Chariri, 2009).

Many qualitative research methods can be used in the investigation of the object under study. They have a distinct and different way of process and adaptation to their problem research. This paper will only describe five traditions that may often be used as a discourse for the research process. Those five traditions are: Biography, Phenomenology, Grounded Theory, Ethnography, dan Case Study (Sukoharsono, 2006).

The study employes case study approach that emphasizes on MDMC (Muhammadyah Disaster Management Center) organization, which specifically has unique disaster management practices, compared to other institutions, which are engaged in similar fields.

Case study is often used to describe a phenomenon. However, there have often been found that some case studies are not described in-depth of a subject of study and somehow those are out of context. Case study is a study to describe a (or some) system structure(s) or case(s) in detail. Sukoharsono argued that case studies include "In-Depth Data Collection Involving Multiple Sources Of Information Rich In Context." Case studies recommend that the investigator must consider how typical cases to be researched are interesting and worthwhile. Cases can be selected singly or collectively, multi-sites or within-sites, and can be focused on a case or issue (intrinsic or instrumental).Yin recommends that there are six information that can be done. Those are documentation, field notes, interview, direct observation, participant observation and physical artifacts. Moreover, Yin adds that typical analysis can be done by holistic analysis of all cases or selected specifically (Sukoharsono, 2006).

Qualitative research is a study that aims to describe and analyze the phenomena, events, social activities, attitudes, beliefs, perceptions, thoughts of individuals and groups. Some descriptions are used to discover the principles and explanations that lead to conclusions. Qualitative research has two main purposes: 1) describe and express (to descibe and explore) and 2) describe and explain (to describe and explain) (Bachri, 2010).

In qualitative research, data collection technique is done on natural settings. Primary data sources and data collection techniques are more on participant observation, in-depth interviews and documentation. Those are as proposed by Chaterine Marshall et al. "the fundamental methods relied on by qualitative researcher for gathering information are, participation in the setting, direct observation, in-depth interviewing, document review" (Bachri, 2010).

Interview is one of data collection techniques in research, particularly qualitative research. There are several types of interviews that need to be identified. Before deciding which techniques to use, we should consider proposed research questions. The research questions' types also 
Available Online at http://journal.unismuh.ac.id/index.php/otoritas

Otoritas : Jurnal Ilmu Pemerintahan, 8 (1), April, 2018, 70

describe the information to obtain (Rachmawati, 2007).

The researcher employ descriptive qualitative research method to describe the data. Thus, the results are analyzed based on the MDMC concept and concluded based on inductive approach. According to Patton, data analysis is the process of arranging the order of data, organizing it into a pattern, category, and basic description unit.

Technically, the researcher collects the data obtained from interview with MDMC organization. Besides, the researcher also collects supporting documents, then systematically organizes them, by using particular classification. It is arranged in sequence, then the data are analyzed. Therefore, it can describedepthresearch results.

According to Wiliam Wiersma, "Triangulation is qualitative crossvalidation. It assesses the sufficiency of the data according to the convergenceof multiple data source or multiple data collection procedures".

Triangulation in credibility test is interpreted as checking data from various sources in various ways and various times. There are three triangulation types, namely: source triangulation, triangulation of data collection techniques and time (Bachri, 2010).

Source triangulation to test the validity of data is done by checking the data that has been obtained to several sources. For example, to test the credibility of the data about the principal's leadership style then the data testing can be examined on teachers and administrative staff of the school.The data obtained are described and categorized; which perspectives are the same, which data are different and which data are specific from those three sources. The data analyzed to draw a conclusion, thenare measured based on the earlier three sources of data. Triangulation techniques to test the credibility of data is done by checking on the same source but with different techniques. For example, data obtained through interviews and then checked with data from observation results, or document analysis results. When having different data, the researcher conducts further discussion with the relevant data source to get the data that is considered as the proper one or maybe everything is true because each data source has a different point of view. (Suryana, 2007).

\section{RESULTS AND DISCUSSION}

\section{Disaster Concept}

The concept of disaster management policy refers to some local and universal concepts. Various models and approaches have been prepared and made then implemented. Non conformities or problems that become obstacles, then appear. Nevertheless, it has given many illustrations and variants that can be an alternative role model to optimize the concept of disaster management.

Disaster management as defined by Agus Rahmat, constitutes all activities covering aspects of disaster planning and mitigation; before, during and after a disaster that are known as disaster management cycle. According to him, the purpose of this activity is to prevent loss of life, reduce human suffering, inform people, authorities about risks, reduce damage to major infrastructure, property and loss of economic resources. Carter defines disaster management as an applied science (applicable) that is seeking, with systematic observation and disaster analysis to increase measures related to prevention, mitigation, preparation, emergency response and recovery.According to him, the objectives of disaster management are to reduce or avoid physical, economic and mental losses experienced by individuals, communities; to reduce the suffering of disaster victims; to have fast recovery; and to provide protection to refugees or people who are lost when their lives are 
Available Online at http://journal.unismuh.ac.id/index.php/otoritas

Otoritas : Jurnal Ilmu Pemerintahan, 8 (1), April, 2018, 71

threatened (Suri, 2015).

Beck formulates the shift of civilization first modernity to second modernity, which resulted in increased risk society. It is the shift of industrial society to the late modern society (late modern society). The shift is marked by the community's understanding of the disaster, a disaster caused by unrecognized human activities and is known to the impact of the disaster that can trigger a growing crisis.According to Giddens modernity is a risky culture. It reduces the risk of a particular field and the needs of human life, but at the same time, it raises a new form of risk that has largely not been known in the past. Disaster studies in the last decade indicate a change of orientation, which initially addresses more technical issues about disaster-triggering events and the handling of disaster victims into an approach that emphasizes the human and community approach.Maskrey also stated that disaster management should not be overcome with a momentary physical approach, but also in accordance with the socio-economic life of local communities that are vulnerable and severely affected by the disaster (Pramono, 2016).

Disaster is often defined in various meanings. Some definitions tend to reflect the following characteristics, such as: 1) deviations that occur in a normal lifestyle. Some deviations are common and also sudden, unexpected and widespread (covering a large area); 2) human suffering, such as death, injury / injury, life difficulties and health problems; 3) damage to social structures such as disruption of government systems, damage to buildings, communications and public service infrastructure or essential services; 4) disruption of community needs, such as shelter, food, clothing, health and social services (Widyastuti, 2005).

Disaster is an event or series of events that cause serious disruption to the community, causing heavy losses; both material, economical and environ- mental aspects. These impacts are beyond the ability of the community to cope with utilizing the resources they have. Based on the causes of the dangers, disasters can be categorized into three, namely natural disasters, social disaster and aggregated disasterNatural disasters are caused by natural events such as earthquakes, tsunamis, volcanoes, and hurricanes. Social disaster or man-made disaster, which results from direct or indirect human actions such as war, social conflict, terrorism and technological failure. Disasters can occur because of nature and people as well as known as aggregated disaster, such as floods and droughts (IDEP, 2007).

The International strategy for Disaster Reduction - The United Nations defines disaster as a serious disruption to the functioning of a society, causing widespread harm to human life from a material, economic, to environmental perspective. This disaster exceeds the people's ability to cope with them using their own resources. Hoesada defines the disaster as a significant interruption of continuity (going concern). Normal and continuous daily operations for an entity, which affects members within entities, entity suppliers, and other stakeholders (Oktarina, 2009).

Disaster is a natural, man-made event or a combination of those two disasters that occur suddenly, causing a devastating negative impact for the survival of life. Moreover, Ministry of Health of the Republic of Indonesia, describes disaster as an event in an area causing ecological damage and loss of human life. Such conditions, therefore, lead to illness and poor health services. Thus, it needs substantial help from external parties (Fauzi, Nurdin, \& Nurdin, 2014).

According to Law Number 24 Year 2007 on Disaster Management, the definition of disaster is as follows: Disaster is an event or series of events that threaten and disrupt people's lives and livelihood caused by both natural and/or non- 
natural factors and human factors. When disaster occurs, damage results such as suffered heavy casualties, environmental damage, property loss, and psychological impact. The definition states that disaster is caused by natural, non-natural, and human factors. Therefore, Law Number 24 Year 2007 also defines natural disasters, non-natural disasters, and social disasters.

Disasters can be (1) natural phenomena such as floods, droughts, earthquakes, storms, natural fires (erupting volcanoes, dry season forest fires, eternal flies, sunlight focus by shrubs of scrub shelled bushes); (2) human negligence such as nuclear plant leakage or gas pipeline, fire due to negligence, accidental oil spill, short circuit, virus disease spread and (3) crimes such as sabotage, arson, blasting, the spread of viruses and the physical destruction of assets. A flood disaster can cause physical losses in billions of USD.

The greatest percentage of disasters may come from fire and water. Water disaster caused by rain, flood and typhoon.Rescued administration and accounting, however are unable to record nonfinancial losses, such as loss of life and relatives, unable to describe sadness, and cannot report historical loss (location of restaurants, legendary hotels, and other heritage assets) (Hoesada, 2012).

The occurrence of natural disasters creates unbelievable events that are unpredictable and predictable because natural disasters will have an tremendous effect, in various areas of life, such as: social, economic, political, cultural. Those impacts are felt and can cause trauma for the victims. Mount Merapieruption in 2010 caused various impacts in the community life order. Community livelihood assets were destroyed and economic production declined. This indicates that people living in the affected areas are losing their jobs (Ratna, 2013).

In fact, there has been no clear an- swer yet whether natural disasters have a significant negative impact on economic growth or not. Some researches explain that in the short term, natural disasters on a large scale negatively affect economic growth. Natural disasters on a large scale have a large impact of damage as well. Damage to physical and / or human capital due to natural disasters leads to lower growth resulting in deviations from previous growth rates (Isa, 2016).

In disaster mitigation of the macroeconomic side observations show that some macroeconomic variables may be affected by the disaster. Disasters are felt on a spatial scale, but here we focus on the impact of disasters at the nation-state or national level, the sub-region, which remains the main unit in development planning (Artiani, 2011).

Natural disasters change people's lives, in various fields. These changes are caused by disaster impacts. Since there are negative impacts following the disaster, it can pose a threat to human existence. Therefore, it needs risk management or disaster management, appropriate and effective, through models and approaches in disaster management practices in the field.

\section{The Model of Disaster Management}

The paradigm of flood risk reduction turns from a responsive mindset into a preventive one by implementing risk management approach. Flood is one of the natural phenomena that potentially cause damage and occurs in certain conditions, period, or areas. Directly or not, the risk of flood loss is predicted to increase gradually, although many efforts have been made to cope. This requires the government and stakeholders to make breakthroughs and cooperations with all parties to create a master plan for Jabodetabek flood prevention (Mauleny, 2015).

The basic concept of communitybased disaster management is the efforts 
to increase community capability or reduce community vulnerability concerning the disaster phenomena. The big number of disaster that happened are the accumulation of some threads along with vulnerability in community. What included as the vulnerability are poverty, unawareness, sensitive nature, helplessness, and other dynamics pressure. Vulnerability in one community has different rote of the problem as well as threads from other communities (Widyastuti, 2005).

Community participation is a process of giving the community wider authority to jointly solve the problems. This authority is divided based on the level of involvement of community in a certain activity. Community participation aims to solve the problems in a better way, by involving the community to contribute to this activity in order to make its implementation effectively, efficiently and sustainably run (UNDP Indonesia, 2012).

Disaster management by using risk management approach is aimed as a media and discourse to integrate the spirit of DRR in regional development planning and to gain the active support and involvement of all components. Therefore, various efforts to synergize the related regulations and persuasive advocacy efforts from various parties toward relevant stakeholders are done to realize that goal (Ahdi, 2015).

Generally, the community empowerment have some processes in preventing ROB flood. The planning of this community empowerment program is implemented into several products, such as self-help mapping, and poverty reduction program. For each step of this community empowerment for preventing ROB flood, the people of Tanjung Mas sub-regency are actively participated in the activities of decision making, implementation, result use, and evaluation (Reizkapuni \& Rahdriawan, 2014).

The approaches of disaster management has several concepts, including pre- ventive approach, community-based approach, and empowerment-based approach. All those approaches have benn already conducted and oriented on how the community or government manage post disaster problems. Therefore, it can effectively help people that socially or psychologically involved in disaster loss.

Attempts of disaster management are conducted in three stages; predisaster, during disaster, and postdisaster. Pre-disaster stage/ period is the preparing time before the disaster coming. The activities included in pre-disaster stage are prevention, mitigation, early warning, and community awareness. In this case, the improvement of community awareness is the most important thing to consider. This is due to the condition in which most victims are in panic and rushing to evacuation place since they are not aware of the situation. As the result, it will cause some chaos (Dito \& Pamungkas, 2015).

Generally, the scope of emergency management are preparedness, response, and recovery. Meanwhile, the inovasion of impact transition phase (right before, during, and after the impact) includes some actions. They are not only plicyoriented actions, but also operationaloriented actions. Of course, they are conducted in the right time of improvisation (Fauzi, Nurdin, \& Nurdin, 2014).

Muhammadiyah tries to propose the disaster management concept based on the spirit of Al Maun. This spirit brings the concept of public helper. In this case, Muhammadiyah attempts to make real actions concerning the community empowerement of mustadin. Thus later on, they will be able to stand on their own.

Related to disaster management matter, Muhammadiyah has independent otganization that concerns on managing disaster. This organization is called as MDMC or Management Disaster Muhammadiyah Centre. It is an institution that focuses on mitigation activities. 
Available Online at http://journal.unismuh.ac.id/index.php/otoritas

Otoritas : Jurnal Ilmu Pemerintahan, 8 (1), April, 2018, 74

\section{Profile of Muhammadiyah Disaster Management Centre}

Muhammadiyah Disaster Management Centre (MDMC) is the disaster management organization that is organized under the Muhammadiyah. This organization is actively participated in social activities. Basically, this intension is natural because from the first time this organization is formed, it has already closesly related to people's poor social condition. The collapsed social system at that time drive it to form a system that weakened the commoners. Besides actively participated the social activities, Muhammadiyah is also a religious movement. This organization has a concept that inspires the da'wahmovements. One of them is the MDMC. This idea of movement is in accordance with the spirit contained in Alma'un.

Disaster may bring great impact for a country, the government, and its people. That is why the main responsibility of disaster management is in the country respectively. Meanwhile, the role of other organizations, such as non-governmental organization, private organizations, civil citizens, and international organizations are the government's partners in accelerating and completing the process of disaster management in Indonesia. Muhammdiyah, as a social organization, is intended to actively participated in the attempts of disaster management. In this case, the active role of Muhammadiyah in activily helping others is needed to be organized accordingly in a certain system of disaster management. Most importantly, this disaster management system must be able to engage the active role of Assembly, autonomous organizations, and other important elements of Muhammadiyah. The main function of disaster management system actually is to ensure that the resource and the performance of the Assembly and autonomous organizations are well coordinated. It is important in order to provide the best service of disaster management. Therefore, once this management system is applied well, accordingly, then the results are: 1) there will be no confusion in management role and coordination between Muhammadiyah Disaster Management Center and the Assembly, organization, and autonomous organizations of Muhammadiyah; 2) there will be no confusion in management role and coordination between Muhammadiyah Disaster Management Center in nationallevel and regional level and management conflict can be avoided; 3 ) the duties in disaster management activities can be conducted effectively, efficiently; and 4) all the activities provided can be optimalized effectively (MDMC, 2012).

Furthermore, Al-Ma'un is the basis ideology of efforts that provide base of taking one side. In this case, Muhammadiyah is taking side of the weaks (dhu'afa) and the persecuted (mustadl'afin). The spirit of Al-Ma'un was the main basis in first attempt of "PKO-Penolong Kesengsaraan Oemoem" (or public helper), the former MDMC, that active in the early period of Muhammadiyah. The figure of this organization is Kyai Sudjak. Thus, this kind of spirit is necessary to be reimplemented as the basis for disaster management system. This new reimplemented spirit should be in accordance with new ideas of establishing civil society. In this case, what is meant by civil society are the open-minded, dignified people. Thus, in establishing civil society, knowledge and technology shoud be put first as the movemnet basis. Basically, from the beginning of Muhammadiyah establishment, its core implies the total, universal inclusivity. This concern is in accordance with the spirit of Islam as a mercy for entire universe. However, this basic core is perceived and implemented differently for times, particularly in the use of language. Even so, phrase "sustainable and enjoyable" should not be forgotten in any Muhammadiyah perfor- 
Available Online at http://journal.unismuh.ac.id/index.php/otoritas

Otoritas : Jurnal Ilmu Pemerintahan, 8 (1), April, 2018, 75

mance. In currently context, the word sustainable and enjoyable should be perceived in new perceptions, namely: 1) Strengthen the commitment to protect the weaks (dhu'afa) and the persecuted (mustadl'afin); 2) facilitate the resources of Muhammadiyah to leave the dominance of globar market: 3 ) build collective awareness and structured cohesiveness; 4) develop social capital as the compensastion of natural resources loss, and improve people trust on human resources management; 5) agent of balance between the democratic process and the good governance. Globally, Muhammadiyah is considered as the pillar of Moderate Islam as well as the democracy millestone in Indonesia. That is why there are some parties that intend to corporate with Muhammadiyah. One of them is Humanitarian Forum Indonesia (HFI). In addition, Muhammadiyah is one of the initiator of this organization. The concerns arose in community Based disaster reductions management is part of Muhammadiyah micro strategy as Islamic civil society resting on the concept of $\mathrm{Al}$ Ma'un. Particularly, this concept includes several processes of love and care, empowerment, social capital, social defense, and civil society (CBDRM) (MDMC, 2012).

In 2007, the General Chairman of Muhammadiyah established Muhammadiyah Disaster management Center by issuing Decree number 58/kep/1.0/2007 on the organizing committee of MDMC. In this period, Dr. H.M. Natsir Nugroho, Sp.OG, M.Kes is appointed to be the chairperson. This decision is based on the internal recommendation on paragraph 1 of Muhammadiyah Congress 45 decision of 2015. Furthermore, during the period of 2010-2015, the General chairman of Muhammadiyah restructured the MDMC to be equal to the assembly level. During this period, H. Budi Setyawan, S.T is appoinred as the chairperson. Besides, tre headquarter is in Yogyakarta (MDMC, 2012).
The organization of Muhammadiyah Disaster Muhammadiyah Centre has been through a long process. It is remarked by the dialogic process that put the spirit of A-Ma'un as its core. Thus, it makes this organization still exists and consistant in providing service in the activities of disaster management. Gradually, this organization tried to expand its efforts. By utilizing the influence of Assembly, the regional level of MDMC are established in order to ease the coordination. One of the regional level of MDMC is MDMC Ponorogo. This regional level of organization is established 3 years ago, but it tries to provide excellent service.

MDMC organization with spirit of $\mathrm{Al}$ -Ma'un as its core has become a model for those that actively engaged in disaster management. However, the consistency of this organization is bondly strong. This is due to its active participation in many disaster management activities, whether it is conducted independently or coorperating with government. The intention to help other people make MDMC as the organization that has further vision comopared to other yet similar organizations. It is said so because other organizations are still focus on aid distribution and trauma healing. Conversely, MDMC has surpassed this step, and now, it is more focus on rehabilitation and empowerement.

Dialogic process based on the concept of Al-Ma'un in the initiation of MDMC makes it organized based on mutual agreement of Muhammadiyah Congress. As what is known that Muhammadiyah Congress is one of big, important agenda of Muhammadiyah. In that congress, the basis of Muhammadiyah Disaster Management Center is defined, including. What is included in the basis are principles, concepts, and coordination patterns of the organization. Later, those aspects becomes the basis of MDMC organization in all regions.

The basic formation of MDMC is the decision of 46th Muhammadiyah Con- 
gress in 2010 issued on the official $\mathrm{Mu}$ hammadiyah news number 1/2010/2015. decisions that directly related to the issue are described as follows: 1) improving and optimizing the disaster management system in form of networkings or emergency responses, rehabilitation in Muhammadiyah environment, capability improvement of cadres and volunteers, and disaster nmanagement; 2) improve disaster awareness in Muhammadiyah environment, campaigning the disaster awareness to the society, advocating the disaster management, and attempting other efforts in post-emergency recovery program systematized with programs and principles of Muhammadiyah; 3) improving the coordination between Muhammadiyah autonomous organization and hospital parties during disaster management, improving the quality of disaster response, improving the quality of logistics management and supply, and postdisaster rehabilitationand recovery (MDMC, 2012).

Meanwhile, decisions that are not directly related to the issue are described as follows: 1) Optimize health services standard through AUMKES (sectors of health) services standardization, hospitals development with excellent service in every area, optimalization of AUMKES services toward public health problem and disaster management, adding more AUMKES number as Hospital satellite Clinic of Muhammadiyah and Aisyiyah in remote areas; 2) facilitating and paving the way to relation improvement, networking, and cooperation among Muhammadiyah international institutions to develop the aspects that will be the focus of Muhammadiyah movement. It includes conflict resolution, disaster management and other important international concerns; 3) making Muhammadiyah branches active as the disaster management center, whether for emergency of recovery phase (MDMC, 2012).

The long, complex process of form- ing the MDMC makes this organization has well-arranged conceptual and contextual plans. Thus, this condition leads into the formulation of basic principles, vision and mission, and active role, responsibility, and values mandated in congress. Later, those above aspects becomes the organization guidelines in helping those in need.

On its way, Muhammadiyah Disaster Management Center is organized based on several principles. Those are: 1) Basic principle. There are some basic principles that can be adopted by MDMC, namely: a) disaster risk reduction (DRR) should be one of important parts of $\mathrm{Mu}-$ hammadiyah investment on sustainable development in order to protect $\mathrm{Mu}$ hamadiyah people and common people and all their assets b) disaster risk reduction (DRR) should be integrated in every work plan and program of Muhammadiyah since hazards have destroyed the development results that effortfully obtained for past hundred years; d) Muhammadiyah through MDMC have to consider the disaster as multihazards to improve organization's effectivity; d) capacity improvement is the main strategy in implementing disaster risk reduction (DRR) in order to develop and maintain the capability of organization, activist, organization members, common people generally in managing the risk well, independently; e) the responsibility of DRR implementation in Muhammadiyah should be decentralized in the level of Muhammadiyah Provincial Executive and Muhammadiyah Regional Executive. This is due to the large area of Indonesia that consists of 33 provinces and 400 regions; f) in society, people's participation is a must to make DRR effective. Disaster Management organization should engage people to actively participate in the preparation and implementation. Thus, it can be ensured that the implemented activities are what people need and in accordance with the level of vernerability; g) disaster manage- 
ment organization concern gender as a main factor in implementing DRR since it is considered as a applicable regulating principle in society. In its root, the women's roles is as environmental resources user and regulator, economy earner, and community workers. Those roles make women are in charge of risk management. Moreover, it is expected that by having 'Aisyiyah and Nasyiatul 'Aisyiyah as the women's movement of Muhammadiyah, it can give additional value to the organization; h) cooperating with independent parties and community institutions in form of voluntarily common association in order to aim the objectives through collaborative activities.

\section{Vision, Mission, and Strategic Position}

The vision of Muhammadiyah Disaster Management Center is "The improvement of excellent function and system of disaster management based on Public Welfare Helper to improve the quality and life progress of people that is aware and firm of hazards and to recover the victims in fast and dignified". The missions of MDMC are: a) to improve and optimize the disaster management system in Muhammadiyah; b) improve disaster awareness in Muhammadiyah environment; c) strengthen the networking and participation of society in disaster management. Generally, the strategic position of MDMC are as follows: 1) disaster management center is a Muhammadiyah practical organization that back to basics in which its movement focus is on da'wah, tarbiyah, and prosperity; 2) conduct organizational empowerment and independent disaster management program as an integrated part of re-enlightment of Muhammadiyah based on the vision of Muhammadiyah 2025 ("Make Muhammadiyah an excellent Islamic movement and create an ideal condition for the realization of real Islamic society") 3) consolidation is conducted along with the challenges and Muhammadiyah participation in global humanitarian activities; 4) get ready to be the global player of Muhammadiyah congress 2015-2020.

\section{Roles, Responsibility, and Values}

The roles of Disaster management center are: a); building awareness; b) being mediator of behavior changing, 3) enhancing participation of society; d) enhancing values, cultures, and community resilience. Then, the responsibility that must be carried by Muhammadiyah Disaster Management Center are: a) accomplish God's mandate (hablunminallah); b) help public welfare (habluminannas). Furthermore, the philosophical values of MDMC include: a) blessing for the entire world; b) justice; and c) professional. Meanwhile, the operational values of MDMC include: a) responsiveness, or serving fast response; b) discussion, or conducting partisipative method; c) effective and efficient, or optimizing resources for the right targets and objectives; d) advancement, or using community empowerment approach; e) networking, or cooperating with other parties carrying the similar missions; f) accountability, or working transparently, respecting public openness concerning financial report; g) law obedience, or acting consciously based on applicable regulations (MDMC, 2012).

The basic concept of MDMC results what is called as organization pattern of MDMC. This is also the causal factor of disaster management organization in regional level. Supported by the assembly decision, this organization has officially established in almost all regions. One of them is in Ponorogo.

The idea about MDMC is to verify those human assets of Muhammadiyah are used ideally that is the reason the best authoritative oversaw economy needed for catastrophe administration (whether pre, whilst, alternately post-disaster) may be Muhammadiyah structure-based management, include: 1) essential of the sys- 
Available Online at http://journal.unismuh.ac.id/index.php/otoritas

Otoritas : Jurnal Ilmu Pemerintahan, 8 (1), April, 2018, 78

tem, this framework adjusts those accessible assets for Dealing with catastrophe. 2) the utilization from claiming $\mathrm{Mu}-$ hammdiyah structural totally, this framework utilization at authoritative networkings about Muhammadiyah structure, including Muhammadiyah commonplace Executives, Muhammadiyah territorial Executives, What's more executives. 3) facilitating with assets outside Muhammadiyah in this case, At whatever assets outside Muhammadiyah nature's domain camwood a chance to be effectively facilitated. 4) catastrophe group keeping investment. A catastrophe provides for effects to a portion group during those same the long haul. However, this catastrophe community is the catastrophe bleeding edge. Thus, catastrophe administration focus ought further bolstering participate their participation, particularly in the viewpoints for preparedness, response, Furthermore recuperation. 6) office What's more uncommon framework Actually, catastrophe management association may be An element substance. Every one disaster administration cycles include true movement. From claiming course, it obliges well-prepared, uncommon frameworks Also offices that as a rule on adapting with: An) bearing and coordination from claiming catastrophe management movements; b) exercises On coordination focal point for crisis reaction if over national, provincial, or territorial level; c) preparation Also framework actuation about catastrophe oversaw economy In necessary; d) communication; e) right on time warning; f) overview and observation; g) data administration; Furthermore h) crisis logistics (MDMC, 2012).

The instrument from claiming recruitment of MDMC Ponorogo parts will be depicted as takes after. In it includes every last bit existing self-sufficient organizations. Those self-sufficient organizations incorporate Hizbul Wathan, Tapak Suci, IPM, IMM, NA, Furthermore Muhammadiyah young. Secondly, those MDMC parts would recruit starting with their particular extensions since there are branch-level catastrophe management organizations. When it hails to training, we need aid troubled with parts of the extension. Inasmuch as to self-sufficient organizations, there are officially differentiate segments for leading MDMC exercises. SAR (Search Also Rescue) is completed Toward Hizbul Wathan What're more Kokam. HDI, IMM, What's more na center all trauma recuperating. Thus, those Different establishments need aid commonly economical. LAZISMU foundations are obliged should deal with accounts. Therefore, accounts about MDMC is centred over person door, LAZISMU.

The previous explanation about MDMC depicts that MDMC is an organization organized by Muhammadiyah. Thus, it has open access to utilize all facilities of Muhammadiyah to support its main duties and functions. Besides, this organization can openly coorperate the disaster management activities with other parties or organizations, even outside Muhammadiyah environment. Simply, MDMC tried to optimize all the human resoursesand financial resources of $\mathrm{Mu}$ hammadiyah in order to support them in their disaster management activities.

Moreover, the organized structure makes MDMC more flexible. In one hand, MDMC is the government's partner. However, in the other hand, it also collaborates with other elements related to certain disaster management. It can be seen from the organizational structures that support the movements of MDMC.

Thus, for the chairperson, it is reasonable that he needs should coordinate every last one of existing parts also being officer What's more field facilitator. When the parts need to behavior movement, that input will be an order. In this case, those field facilitator is ahmad fauzi huda. Those particular occupation of the vice executive will be with representable that executive if absent. After that the vice ex- 
Available Online at http://journal.unismuh.ac.id/index.php/otoritas

Otoritas : Jurnal Ilmu Pemerintahan, 8 (1), April, 2018, 79

ecutive will be those reinstatement officer. Secretary is tasked with fare thee well from claiming organization matters for MDMC. Those undertaking of the preparedness field may be on behavior the Initially study when catastrophe strikes. For sample may be providing for an publication of the occupants that this range is inclined should landslides. To prevention, quick relief officers are sanctioned should behavior those initial overview alternately certification. That crisis reaction is what is finished today. When catastrophe strikes, those crisis parts must deal with how every last one of assets in the coordination focal point. Those field about restoration What's more collaboration does its worth of effort then afterward the catastrophe happens Furthermore it needs to be been proclaimed sheltered starting to the catastrophe. Following that, it may be attempted with restore the state Similarly as When. This is carried Eventually Tom's perusing the restoration area. The field of logistics manages the sum approaching logistics, distributes, Also also manages those logistics in the post. What's more, they are also keeping in touch with you must be clear in your reasoning something like how not will run out of logistics. Logistics here might be in the structure from claiming money, food, alternately supplies. That production field is answerable for distributed alternately generating news identifying with calamitous occasions. Afterward, the news will be disseminated and distributed should the sum components from claiming culture.

MDMC may be positioned as An legislature backing less group should behavior Different exercises What's more catastrophe mapping field. This is done in place to think those current state in the debacle range. This data may be used to aggravate those necessity scale to catastrophe victimized people group keeping. In additional, from that information, we immediate Different supports, for exam- ple, such that trusts or vitality of the exploited people to need. Currently, we need aid conveying of Different Muhammadiyah benefits of the business philanthropy and additionally related gatherings should make group keeping strengthening system. It may be pointed should restore those battling control or the survival for influenced groups in place on recuperating. In addition, we are likewise open to Different partnerships. Thus, the gatherings from outside Muhammadiayah Might endow us.

This organizational engagement is the basis of the organization to show its existence in many disaster management activities. One of them is during landslide in Banaran, Pulung, Ponorogo. in this case, MDMC is one of teams that focus and consistent in the disaster management activities. It provides several sercives, namely: trauma healing, religious activities, soup kitchen, health center, and evacuation team. Therefore, it is clear that MDMC has effective function when disaster takes place. MDMC routines in disaster management activities can be inferred from its various activities in disaster location.

Generally speaking, MDMC has organizational structures and good supports of Muhammadiyah. Those, then, become the social basis for this organization to make coorperatio with other autonomous organizations of Muhammadiyah. Of course, it is conducted based on the situation, condition, and necessity of disaster location. Conversely, due to their narrow scope, other disaster management organizations face difficulties in developing networking, especially that is related to organization management and mobilization of disaster management. This condition, surely, will influence their effectivity in accomplishing their duties. 
Available Online at http://journal.unismuh.ac.id/index.php/otoritas

Otoritas : Jurnal Ilmu Pemerintahan, 8 (1), April, 2018, 80

\section{CONCLUSION}

Spirit of $\mathrm{Al}$ - Maun has made MDMC colorful and has distinguished characteristic in conducting disaster management activities. The spirit is clearly depicted from the supportive organizational management to obtain the objectives of helping those in need (mustadi'in). It is realized in partnership activities with other Muhammadiyah autonomous organizations or with other parties, such as government or private institutions. Moreover, it is realized by MDMC through disaster management activities, including identification, reconstruction, rehabilitation, and recovery for the disaster victims. This what makes MDMC has good vision in conducting disaster management. It can be seen from its active participation in many disaster management program. Even though they have been accepted well by the society, however, the practices of MDMC need to be developed. This is due to the condition that MDMC is established in only few years ago. In this case, the process of cadre training becomes one of the concerns since the technical ability of disaster management of its members is necessary to be improved. Besides, the nerworking and cooperation built by MDMC should be maintained professionally. Therefore, any form of miss communication during the realization disaster management activities can be minimized. As the result, MDMC can accomplish the duties well.

\section{ACKNOWLEDGEMENT}

The author thankful to our colleagues in Department of Governmental Science, Faculty of Social and Political Sciences, Universitas Muhammadiyah Ponorogo, Indonesia.

\section{REFERENCES}

Agustina, D. (2016). Peran Lembaga Muhammadiyah Disaster Management Center (MDMC) dalam Proses
Manajemen Bencana Gunung

Kelud di Kabupaten Malang. (Doctoral dissertation, University of Muhammadiyah Malang).

Ahdi, D. (2015). Perencanaan Penanggulangan Bencana Melalui Pendekatan Manajemen Risiko. REFORMASI, 5(1), 13-30.

Artiani, L. E. (2011). Dampak Ekonomi Makro Bencana: Interaksi Bencana dan Pembangunan Ekonomi Nasional. In Seminar Nasional Informatika (SEMNASIF) (Vol. 1, No. 5).

Bachri, B. S. (2010). Meyakinkan validitas data melalui triangulasi pada penelitian kualitatif. Jurnal Teknologi Pendidikan, 10(1), 4662.

Badan Pusat Statistik. (2015). Jawa Timur Dalam Angka. Surabaya: Badan Pusat Statistik Jawa Timur.

Chariri, A. (2009). Landasan Filsafat Dan Metode Penelitian Kualitatif. Laboratorium Pengembangan Akuntansi (LPA), Fakultas Ekonomi Universitas Diponegoro Semarang.

Dito, A. H., \& Pamungkas, A. (2016). Penentuan Variabel dalam Optimasi Jalur Evakuasi Bencana Tsunami di Kecamatan Puger, Kabupaten Jember. Jurnal Teknik ITS, 4 (2), C161-C164.

Fauzi, L. M., Nurdin, A., \& Nurdin, I. (2017). Peran Tentara Nasional Indonesia dalam Penanggulangan Bencana di Provinsi Daerah Istimewa Yogyakarta. Jurnal Ilmu Politik dan Komunikasi, 4(02).

Hoesada, J. (2012). Disaster Recovery Planning: Manajemen Bencana Administrasi dan Akuntansi.

IDEP. (2007). Panduan Umum Penanggulangan Bencana Berbasis 
Available Online at http://journal.unismuh.ac.id/index.php/otoritas

Otoritas : Jurnal Ilmu Pemerintahan, 8 (1), April, 2018, 81

Masyarakat. Jakarta: IDEP.

Isa, M. (2016). Bencana Alam: Berdampak Positif Atau Negatif Terhadap Pertumbuhan Ekonomi. In The 3rd University Research Colloquium.

Kurniawati, C. P. (2015). Kajian Permasalahan Kebijakan Penetapan Status Bencana, Kelembagaan BPBD, dan Pengelolaan Bantuan Pasca Terbitnya UU Nomor 24 Tahun 2007. Jurnal Tata Kelola \& Akuntabilitas Keuangan Negara, 1(1), 95-106.

Lestari, P., Sembiring, I. D. P. B., Prabowo, A., Wibawa, A., \& Hendariningrum, R. (2013). Manajemen Komunikasi Bencana Gunung Sinabung 2010 Saat Tanggap Darurat. Jurnal ILMU KOMUNIKASI, $10(2)$.

Mauleny, A. T. (2015). Aglomerasi, Perubahan Sosial Ekonomi, dan Kebijakan Pembangunan Jakarta. Jurnal Ekonomi dan Kebijakan Publik, 6(2), 147-162.

MDMC. (2012). Lembaga Penanggulangan Bencana Pimpinan Pusat Muhammadiyah. Yogyakarta: MDMC PP Muhammadiyah.

Oktarina, R. (2009). Konseptual Perancangan Sistem Informasi/ Manajemen Logistik Penanggulangan Bencana (SIMLOG-PB) Berbasis GIS (Geographic Information System) di Indonesia.

Pramono, R. (2016). Perspektif Sosiologis Dalam Penanggulangan Bencana Sociological Perspectives in Disaster Management. Jurnal Masyarakat dan Budaya, 18(1), 81-96.

Rachmawati, I. N. (2007). Pengumpulan data dalam penelitian kualitatif: wawancara. Jurnal Keperawatan Indonesia, 11(1), 35-40.

Reizkapuni, R., \& Rahdriawan, M. (2014). Pemberdayaan Masyarakat dalam
Penanggulangan Banjir Rob Di Kelurahan Tanjung Mas Kota Semarang. Teknik PWK (Perencanaan Wilayah Kota), 3(1), 154-164.

Sukoharsono, E. G. (2006). Alternatif Riset Kualitatif Sains Akuntansi: Biografi, Phenomenologi, Grounded Theory, Critical Ethnografi dan Case Study. Badan Penerbit Fakultas Ekonomi Universitas Brawijaya. Malang. C Centre for Indonesian Accounting and Management Research.

Suri, N. K. (2016). Analisis Kinerja Badan Penanggulangan Bencana Daerah Kabupaten Karo Dalam Upaya Penanggulangan Bencana Erupsi Gunung Sinabung di Kabupaten Karo. PERSPEKTIF, 8(1).

Suryana, C. (2007). Pengolahan Dan Analisis. Jakarta: Departemen Pendidikan Nasional.

Syarif, A., \& Unde, A. A. (2016). Pentingnya Komunikasi dan Informasi pada Implementasi Kebijakan Penyelenggaran Penanggulangan Bencana di Kota Makassar. KAREBA: Jurnal Ilmu Komunikasi, 3(3), 142-152.

UNDP Indonesia. (2012). Making Aceh Safer through Disaster Risk Reduction in Development. Jakarta: UNDP Indonesia.

Widyastuti, M. (2012). Manajemen Bencana: Kajian dan Ruang Lingkup. Jurnal FISIP: MADANI, 2(02).

Wijayanti, A. R. W. (2013). Perubahan Pekerjaan Masyarakat Sebagai Akibat dari Bencana, Studi Kasus: Kawasan Wisata Volcano Tour Gunung Merapi, Desa Umbulharjo, Kecamatan Cangkringan, Kabupaten Sleman. Jurnal Perencanaan Wilayah dan Kota, 24(1), 19-34. 